\title{
Could antibodies to C-reactive protein link inflammation and cardiovascular disease in patients with systemic lupus erythematosus?
}

\section{Sean G O'Neill, David A Isenberg, Anisur Rahman}

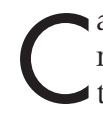
ardiovascular disease (CVD) is a major cause of morbidity and mortality in patients with systemic lupus erythematosus (SLE). Most patients with SLE are young women who would normally be very unlikely to develop CVD. In women with SLE aged 35-44, the risk of CVD is up to 50 times that of age- and sex-matched controls. ${ }^{1}$ Several studies have examined the possible reasons for this increased risk. Although traditional risk factors such as hypertension, smoking and lipid levels contribute part of the increased risk, they do not explain all of it. ${ }^{2-4}$

Atherosclerosis is an inflammatory condition. As SLE is characterised by inflammatory flares affecting different organs and tissues of the body, it has been suggested that these flares contribute to the development of atherosclerosis. ${ }^{5}$ SLE is also characterised by the presence of autoantibodies. Some of these can contribute to development of cardiovascular disease by promoting atherosclerosis. Antiphospholipid antibodies (APL), for example, promote arterial and venous thrombosis ${ }^{6}$ and activate endothelial cells. However, levels of APL have rarely been linked to disease activity in SLE patients, and a recent study in 200 patients with SLE showed that the prevalence of carotid artery plaques did not differ between APL-positive and APLnegative patients. ${ }^{7}$ Other antibodies could potentially exert a direct action on cardiac tissue. This is recognised in the foetal heart where anti-Ro antibodies crossing from the maternal circulation attack the conducting tissue to cause foetal heart block. ${ }^{8}$ However, it should be stressed that anti-Ro antibodies do not affect the adult heart and levels of anti-Ro do not reflect SLE disease activity.

Are there other autoantibodies that could link inflammatory disease activity and CVD in SLE? There are a number of possible candidates, including anti-high density lipoprotein $^{9}$ and anti-apolipoprotein A- $1 .{ }^{10}$
In this editorial, we discuss the possibility that anti-C-reactive protein (CRP) antibodies could also play such a role in this link.

\section{CRP AND ANTI-CRP IN SLE}

CRP, a marker of inflammation, is an independent predictor of CVD. This has been shown in large prospective studies in adults with no previous history of CVD. ${ }^{11}{ }^{12}$ The predictive effect of raised CRP is moderate and the mechanism is not clearly understood. ${ }^{13}$ The study of CRP in animal models is complicated by the fact that CRP is only a trace protein in mice and neither mouse nor rat CRP fixes complement. ${ }^{13}$ Human CRP infused into mice or rats does fix complement, and such infusions enhanced the amount of cardiac infarction caused by ligation of the coronary artery in rats. ${ }^{14}$ This effect was abrogated by complement depletion. Vascular injury causes more thrombosis in mice transgenic for human CRP than in congenic wild-type mice. ${ }^{15}$ Apolipoprotein E-deficient mice that were also transgenic for human CRP were reported to develop enhanced atherosclerosis compared to non-transgenic apolipoprotein E- deficient mice. ${ }^{16}$ Conversely, a second group found that the human CRP transgene exerted no such effect in these mice. ${ }^{17}$ In humans, it seems likely that CRP is deposited in ischaemic cardiac tissue, fixes complement and thus causes cardiac damage. In support of this, Lagrand et al carried out immunohistochemical studies of cardiac tissue obtained from autopsies of 17 patients who died after acute myocardial infarction and showed co-localisation of CRP and complement in infarcted but not healthy areas of myocardium. ${ }^{18}$ In blood vessels, CRP can bind to low density lipoprotein (LDL), altering its uptake into atherosclerotic plaques. ${ }^{13}$

So could CRP itself be the link between disease activity and CVD in SLE? One problem with this hypothesis is that CRP levels are not highly elevated in flares of
SLE, although large population studies do show links between CVD and CRP at levels below $10 \mathrm{mg} / \mathrm{l} .{ }^{11}{ }^{12}$ However, many of these studies assessed very few young women, so that their relevance to SLE could be limited. Another problem is the modest effect of raised CRP concentration. In the Reykjavik study, patients in the highest tertile of baseline CRP concentration had a 1.45 times higher risk of developing CVD than those in the lowest tertile. ${ }^{12}$ This could explain no more than a small proportion of the excess risk of CVD in SLE.

What about antibodies to CRP? These were first reported in patients with SLE by Bell et al in 1998. ${ }^{19}$ This finding has been confirmed by several groups who showed that anti-CRP antibodies are found in between $23 \%$ and $78 \%$ of patients with SLE, but occur very rarely in healthy controls. ${ }^{19-23}$ Reports from groups in Sweden ${ }^{21} 23$ and the USA ${ }^{1922}$ show that anti-CRP levels do not correlate with serum CRP but might correlate with disease activity. In particular, anti-CRP levels rise during renal flares. In a recent study, Figueredo et $a l^{20}$ confirmed that patients with SLE and active nephritis were more likely to have anti-CRP antibodies than those without nephritis, and also showed that anti-CRP antibodies were associated with increased risk of APL positivity, thrombosis and foetal loss.

Serum anti-CRP antibodies do not bind native pentameric CRP, but bind monomeric CRP (mCRP). ${ }^{19} 23$ Native CRP (nCRP) dissociates spontaneously into mCRP in vitro in the absence of calcium ions, but it is not clear whether mCRP exists in vivo. Some authors contend that mCRP is very unlikely to exist within the body, ${ }^{13}$ whereas others suggest that it is present in blood vessel walls. ${ }^{24}$ If the latter supposition is correct, then mCRP could exert biological effects on blood vessels. ${ }^{25}$ There is some evidence for this, but it is not clear whether mCRP promotes atherosclerosis or protects against it. In apolipoprotein E knockout mice, subcutaneous injections of nCRP enhanced development of atheroma whereas mCRP reduced it. ${ }^{26}$ Conversely, another study suggested that mCRP and nCRP have proatherogenic effects on human aortic endothelial cells in vitro. ${ }^{27}$ Free mCRP blocks complement activation whereas mCRP bound to oxidised or enzymatically modified LDL activates complement. ${ }^{28}$ This complement activation could clearly contribute to development of atheroma, especially as CRP and LDL levels are independent predictors of the development of CVD. ${ }^{11}$

The fact that antibodies specific for mCRP, but not nCRP, exist in patients with SLE suggests strongly that mCRP 
must exist in these patients and that it acts as an antigen. The currently favoured explanation for development of autoantibodies in SLE proposes that apoptotic cell debris is not cleared efficiently by phagocytes in patients with $\operatorname{SLE}^{29}$ so that antigens on the surface of these cell fragments can act as immunogens. ${ }^{30} \mathrm{CRP}$ is involved in the clearance of this material by phagocytes, and it has been proposed that under the acidic conditions prevalent in inflamed tissues nCRP could dissociate to form mCRP..$^{23}$ Thus, mCRP on the surface of apoptotic cell fragments could be the driving antigen for production of anti-CRP in patients with SLE and this process could be enhanced during acute inflammatory flares of the disease. These ideas have been proposed particularly by Sjowall and colleagues, who have published a series of important papers on the subject of CRP and anti-CRP in SLE, ${ }^{21} 2325$, which they have reviewed recently. ${ }^{31}$

Our hypothesis is therefore that disease activity and CVD in patients with SLE are linked by the production of anti-CRP antibodies that interact with mCRP in vascular tissue to promote the production of atherosclerosis. The hypothesis predicts that raised anti-CRP levels in patients with SLE could be an independent predictor of the development of CVD, even after adjusting for other risk factors.

\section{HOW COULD INVESTIGATORS TEST FOR AN ASSOCIATION BETWEEN ANTI-CRP AND CVD IN PATIENTS WITH SLE?}

Experiments in animal models would involve introducing human anti-CRP and human CRP into the animals, because mouse and rat CRP are functionally different to human CRP. ${ }^{13}$ It might be informative to carry out experiments with appropriate control groups (e.g. mice exposed to human CRP only, anti-CRP only or both) or to introduce human antiCRP into mice transgenic for human CRP. ${ }^{15}$ However, this transgene is only expressed at high levels in male mice, which is problematic in trying to model SLE as it is a disease that occurs predominantly in women.

Human studies would involve testing anti-CRP levels in patients with SLE repeatedly to allow for the fact that these levels vary with disease activity. The patient group could be subdivided into tertiles according to mean anti-CRP level or into those who either had or had not experienced a rise in anti-CRP. Clinical outcomes in these subgroups would then be determined.

Studies looking at associations between serum measurements and the incidence of CVD events in cohorts of patients with SLE are difficult, because the overall number of CVD events in the cohort is invariably low even though the relative risk for CVD is high. Figueredo et al ${ }^{20}$ found that the presence of anti-CRP antibodies was associated with thrombosis/foetal loss in 137 patients with SLE, but the number of patients with arterial CVD was not reported. Many patients in multiple centres are needed to collect enough cases of arterial CVD to detect statistically significant associations. ${ }^{3}$ Studying large numbers of patients also enables investigators to carry out multivariable analysis to identify independent risk factors for development of CVD. ${ }^{3} 4$

An alternative approach would be to study associations between anti-CRP antibody levels and sub-clinical surrogate markers of CVD, such as coronary artery calcification measured by electron beam tomography (EBT) or carotid plaque detected by ultrasound scanning. ${ }^{532}$ EBT $^{32}$ and carotid ultrasound ${ }^{5}$ have shown cardiovascular abnormalities in patients with SLE, compared to age- and sex-matched controls. However, the predictive value of these measures for CVD in patients with SLE has not been established and the relationship between these sub-clinical cardiovascular abnormalities and inflammatory activity is not clear.

It might be necessary to carry out all three types of study; effects of anti-CRP in mice, prolonged multi-centre studies of CVD event rates in patients, and shorter human studies using surrogate markers of CVD. These studies are important because we do not know which patients would benefit from more aggressive treatment of inflammation in SLE by gaining better long-term cardiovascular outcome. It would be very useful to discover whether repeated measurements of anti-CRP could be used to help identify these patients.

Ann Rheum Dis 2007;66:989-991.

doi: 10.1136/ard.2007.073312

\section{Authors' affiliations \\ Sean G O'Neill, David A Isenberg, Anisur}

Rahman, Centre for Rheumatology, Division of Medicine, University College London, UK

Correspondence to: Dr Anisur Rahman, Reader in Rheumatology, Room 331, Windeyer Institute, 46 Cleveland Street, London WIT 4JF; anisur.rahman@ucl.ac.uk

\section{Accepted 3 April 2007}

Sean $\mathrm{O}^{\prime} \mathrm{Neill}$ is supported by a travelling fellowship (the Leanne Stafford Award) from The Australian Rheumatology Association and the Arthritis Foundation New South Wales.

\section{Competing interests: None.}

All three authors participated in writing this article, and all three authors saw and approved the final version.

\section{REFERENCES}

1 Manzi S, Meilahn EN, Rairie JE, Conte CG, Medsger TA Jr. Jansen-McWilliams L, et al. Agespecific incidence rates of myocardial infarction and angina in women with systemic lupus erythematosus: comparison with the Framingham Study, Am J Epidemiol 1997; 145:408-15.

2 Bessant R, Hingorani A, Patel L, MacGregor A, Isenberg DA, Rahman A. Risk of coronary heart disease and stroke in a large British cohort of patients with systemic lupus erythematosus. Rheumatology (Oxford) 2004;43:924-9.

3 Bruce IN. 'Not only. but also': factors that contribute to accelerated atherosclerosis and premature coronary heart disease in systemic lupus erythematosus, Rheumatology (Oxford) 2005;44: 1492-502.

4 Esdaile JM, Abrahamowicz M, Grodzicky T, Li Y, Panaritis C, du Berger R, et al. Traditional Framingham risk factors fail to fully account for accelerated atherosclerosis in systemic lupus erythematosus. Arthritis Rheum 2001;44:2331-7.

5 Roman MJ, Shanker BA, Davis A, Lockshin MD, Sammaritano L, Simantov R, et al. Prevalence and correlates of accelerated atherosclerosis in systemic lupus erythematosus. N Engl J Med 2003;349:2399-406.

6 Cervera R, Piette JC, Font J, Khamashta MA, Shoenfeld Y, Camps MT, et al. Antiphospholipid syndrome: clinical and immunologic manifestations and patterns of disease expression in a cohort of 1,000 patients. Arthritis Rheum 2002;46:1019-27.

7 Farzaneh-Far A, Roman M, Lockshin MD, Devereux RB, Paget SA, Crow MK, et al. Relationship of antiphospholipid antibodies to cardiovascular manifestations of systemic lupus erythematosus. Arthritis Rheum 2006;54:3918-3925.

8 Buyon JP, Clancy RM. Maternal autoantibodies and congenital heart block: mediators, markers, and therapeutic approach. Semin Arthritis Rheum 2003:33:140-54.

9 Delgado Alves J, Ames PR, Donohue S, Stanyer L, Nourooz-Zadeh J, Ravirajan C, et al. Antibodies to high-density lipoprotein and $\beta 2$-glycoprotein I are inversely correlated with paraoxonase activity in systemic lupus erythematosus and primary antiphospholipid syndrome. Arthritis Rheum 2002;46:2686-94.

10 Vuilleumier N, Reber G, James R, Burger D, de Moerloose P, Dayer JM, et al. Presence of autoantibodies to apolipoprotein A-1 in patients with acute coronary syndrome further links autoimmunity to cardiovascular disease. J Autoimmun 2004;23:353-60.

11 Ridker PM, Rifai N, Rose L, Buring JE, Cook NR Comparison of $\mathrm{C}$-reactive protein and low-density lipoprotein cholesterol levels in the prediction of first cardiovascular events. N Engl J Med 2002;347: 1557-65.

12 Danesh J, Wheeler JG, Hirschfield GM, Eda S, Eiriksdottir G, Rumley A, et al. C-reactive protein and other circulating markers of inflammation in the prediction of coronary heart disease. N Engl J Med 2004:350:1387-97.

13 Pepys MB, Hirschfield GM. C-reactive protein: a critical update. J Clin Invest 2003;1 11:1805-12.

14 Griselli M, Herbert J, Hutchinson WL, Taylor KM, Sohail M, Krausz T, et al. C-reactive protein and complement are important mediators of tissue damage in acute myocardial infarction. J Exp Med 1999; 190: 1733-40

15 Danenberg HD, Szalai AJ, Swaminathan RV, Peng L, Chen Z, Seifert P, et al. Increased thrombosis after arterial injury in human $\mathrm{C}$-reactive protein-transgenic mice. Circulation 2003; 108:512-5.

16 Paul A, Ko KW, Li L, Yechoor V, McCrory MA Szalai AJ, et al. C-reactive protein accelerates the progression of atherosclerosis in apolipoprotein Edeficient mice. Circulation 2004; 109:647-55.

17 Hirschfield GM, Gallimore JR, Kahan MC, Hutchinson WL, Sabin CA, Benson GM, et al. Transgenic human $\mathrm{C}$-reactive protein is not proatherogenic in apolipoprotein E-deficient mice. Proc Natl Acad Sci USA 2005; 102:8309-14.

18 Lagrand WK, Niessen HW, Wolbink GJ, Jaspars LH, Visser CA, Verheugt FW, et al. Creactive protein colocalizes with complement in 
human hearts during acute myocardial infarction Circulation 1997:95:97-103.

19 Bell SA, Faust H, Schmid A, Meurer M Autoantibodies to C-reactive protein (CRP) and other acute-phase proteins in systemic autoimmune diseases. Clin Exp Immunol 1998;1 13:327-32.

20 Figueredo MA, Rodriguez A, Ruiz-Yague $M$, Romero M, Fernandez-Cruz A, Gomez-de la Concha $\mathrm{E}$, et al. Autoantibodies against $\mathrm{C}$-reactive protein: clinical associations in systemic lupus erythematosus and primary antiphospholipid syndrome. J Rheumatol 2006:33:1980-6.

21 Sjowall C, Eriksson P, Almer S, Skogh T. Autoantibodies to $\mathrm{C}$-reactive protein is a common finding in SLE, but not in primary Sjogren's syndrome, rheumatoid arthritis or inflammatory bowel disease. J Autoimmun 2002; 19:155-60

22 Rosenau BJ, Schur PH. Antibodies to $C$ reactive protein. Ann Rheum Dis 2006:65:674-6.

23 Sjowall C, Bengtsson AA, Sturfelt G, Skogh T. Serum levels of autoantibodies against monomeric
C-reactive protein are correlated with disease activity in systemic lupus erythematosus. Arthritis Res Ther 2004;6:R87-94.

24 Diehl EE, Haines GK 3rd, Radosevich JA, Potempa LA. Immunohistochemical localization of modified C-reactive protein antigen in normal vascular tissue. Am J Med Sci 2000;319:79-83.

25 Sjowall C, Bengtsson, T. Skogh, T. CRP and antiCRP antibodies in systemic lupus erythematosus. Curr Rheumatol Rev 2005;1:81-89.

26 Schwedler SB, Amann K, Wernicke K, Krebs A Nauck M, Wanner C, et al. Native C-reactive protein increases whereas modified C-reactive protein reduces atherosclerosis in apolipoprotein Eknockout mice. Circulation 2005;112:1016-23.

27 Devaraj S, Venugopal S, Jialal I. Native pentameric C-reactive protein displays more potent proatherogenic activities in human aortic endothelial cells than modified $\mathrm{C}$-reactive protein. Atherosclerosis 2006;184:48-52
28 Ji SR, Wu Y, Potempa LA, Liang YH, Zhao J. Effect of modified $\mathrm{C}$-reactive protein on complement activation: a possible complement regulatory role of modified or monomeric $\mathrm{C}$-reactive protein in atherosclerotic lesions. Arterioscler Thromb Vas Biol 2006;26:935-41.

29 Herrmann M, Voll RE, Zoller OM, Hagenhofer M, Ponner BB, Kalden JR. Impaired phagocytosis of apoptotic cell material by monocyte-derived macrophages from patients with systemic lupus erythematosus. Arthritis Rheum 1998;41:1241-50.

30 Walport MJ. Complement and systemic lupus erythematosus. Arthritis Res 2002;4(Suppl 3):S279-93.

31 Sjowall C, Wettero J. Pathogenic implications for autoantibodies against $\mathrm{C}$-reactive protein and other acute phase proteins. Clin Chim Acto 2007;378: 13-23.

32 Asanuma Y, Oeser A, Shintani AK, Turner E, Olsen N, Fazio $S$, et al. Premature coronary-artery atherosclerosis in systemic lupus erythematosus. N Engl J Med 2003;349:2407-15.

\section{BMJ Clinical Evidence-Call for contributors}

BMJ Clinical Evidence is a continuously updated evidence-based journal available worldwide on the internet which publishes commissioned systematic reviews. BMJ Clinical Evidence needs to recruit new contributors. Contributors are healthcare professionals or epidemiologists with experience in evidence-based medicine, with the ability to write in a concise and structured way and relevant clinical expertise.

Areas for which we are currently seeking contributors:

- Secondary prevention of ischaemic cardiac events

- Acute myocardial infarction

- MRSA (treatment)

- Bacterial conjunctivitis

However, we are always looking for contributors, so do not let this list discourage you.

Being a contributor involves:

- Selecting from a validated, screened search (performed by in-house Information Specialists) valid studies for inclusion.

- Documenting your decisions about which studies to include on an inclusion and exclusion form, which we will publish.

- Writing the text to a highly structured template (about 1500-3000 words), using evidence from the final studies chosen, within 8-10 weeks of receiving the literature search.

- Working with BMJ Clinical Evidence editors to ensure that the final text meets quality and style standards.

- Updating the text every 12 months using any new, sound evidence that becomes available. The BMJ Clinical Evidence in-house team will conduct the searches for contributors; your task is to filter out high quality studies and incorporate them into the existing text.

- To expand the review to include a new question about once every 12 months.

In return, contributors will see their work published in a highly-rewarded peer-reviewed international medical journal. They also receive a small honorarium for their efforts.

If you would like to become a contributor for BMJ Clinical Evidence or require more information about what this involves please send your contact details and a copy of your CV, clearly stating the clinical area you are interested in, to CECommissioning@bmigroup.com.

\section{Call for peer reviewers}

BMJ Clinical Evidence also needs to recruit new peer reviewers specifically with an interest in the clinical areas stated above, and also others related to general practice. Peer reviewers are healthcare professionals or epidemiologists with experience in evidence-based medicine. As a peer reviewer you would be asked for your views on the clinical relevance, validity and accessibility of specific reviews within the journal, and their usefulness to the intended audience (international generalists and healthcare professionals, possibly with limited statistical knowledge). Reviews are usually 1500-3000 words in length and we would ask you to review between 2-5 systematic reviews per year. The peer review process takes place throughout the year, and our turnaround time for each review is 10-14 days. In return peer reviewers receive free access to BMJ Clinical Evidence for 3 months for each review.

If you are interested in becoming a peer reviewer for BMJ Clinical Evidence, please complete the peer review questionnaire at www.clinicalevidence.com/ceweb/contribute/peerreviewer.jsp 